Article

\title{
Treatment of Winery Wastewater Using Bench-Scale Columns Simulating Vertical Flow Constructed Wetlands with Adsorption Media
}

\author{
Katelyn Skornia ${ }^{1}$, Steven I. Safferman ${ }^{1, *}$, Laura Rodriguez-Gonzalez ${ }^{2}$ and Sarina J. Ergas ${ }^{2}$ (D) \\ 1 Department of Biosystems and Agricultural Engineering, Michigan State University, East Lansing, MI 48824, \\ USA; skorniak@msu.edu \\ 2 Department of Civil and Environmental Engineering, University of South Florida, Tampa, FL 33620, USA; \\ lauracamille@mail.usf.edu (L.R.-G.); sergas@usf.edu (S.J.E.) \\ * Correspondence: steves@msu.edu; Tel.: +1-517-432-0812
}

Received: 21 December 2019; Accepted: 27 January 2020; Published: 5 February 2020

check for updates

\begin{abstract}
Wastewater produced during the wine-making process often contains an order of magnitude greater chemical oxygen demand (COD) concentration than is typical of domestic wastewater. This waste stream is also highly variable in flow and composition due to the seasonality of wine-making. The recent growth of small-scale wineries in cold climates and increasing regulations present a need for low-cost, easily-operable treatment systems that do not require large amounts of land, yet maintain a high level of treatment in cool temperatures. This research investigates the use of a subsurface vertical flow constructed wetland (SVFCW) to treat winery wastewater. In this study, clinoptilolite, tire chips, and a nano-enhanced iron foam were used to enhance bench-scale gravel cells to adsorb ammonia, nitrate, and phosphorus, respectively. The treatment systems, without nitrogen adsorption media, performed well, with $>99 \%$ removal of COD and $94 \%$ removal of total nitrogen. Treatment systems with the nitrogen adsorption media did not enhance nitrogen removal. Equilibrium was reached within two weeks of start-up, regardless of prior inoculation, which suggests that microbes present in the winery wastewater are sufficient for the start-up of the wastewater treatment system; therefore, the seasonality of winery wastewater production will not substantially impact treatment. Operating the treatment systems under cool temperatures did not significantly impact COD or total nitrogen removal. Further, the use of nano-enhanced iron foam exhibited $99.8 \%$ removal of phosphorus, which resulted in effluent concentrations that were below $0.102 \mathrm{mg} / \mathrm{L} \mathrm{P}$.
\end{abstract}

Keywords: winery wastewater; constructed wetland; cold weather wetland; vertical flow wetland; nutrient adsorption

\section{Introduction}

In 2018, wine production reached a record volume, with over 293 million hectoliters being produced globally [1]. As the largest consumer, the United States is also the fourth-largest producer of wine globally [1]. Wine produced in the United States comes from wineries of many sizes; wineries that produce over 500,000 cases per year are considered to be large, and wineries producing less than 50,000 cases per year are small [2]. Currently, only 341 of the 10,185 wineries in the United States are classified as medium or large, and the rest are classified as small, very small, or limited production [2]. These smaller wineries dominate the Michigan wine industry. In 2018, there were nearly 150 wineries [3], $71 \%$ of which were ten acres or less in size [4]. These 150 wineries bottle more than 11.3 million liters (>3 million gallons) of wine annually [5]. It is estimated that, for every liter of wine produced, 2.86-4 L of wastewater is generated [6,7], which suggested that Michigan produced 45.4 million liters (12 million gallons) of winery wastewater in 2018. 
The composition of winery wastewater is highly variable between wineries as a result of general management practices, the amount of water used, the size and design of the winery, and different wine-making techniques [8-12]. Winery wastewater quantity and quality vary, even within a single winery due to the various steps in wine-making and the type of wine produced $[6,9,11,12]$. Wastewater is generated throughout the wine-making process, which has five distinct stages: harvest, crush, fermentation, racking and clarification, and aging and bottling. The harvest period produces the highest chemical oxygen demand (COD) strength wastewater and accounts for the largest volume of winery wastewater produced $[8,13]$. Small wineries may generate up to $80 \%$ of their wastewater during this period [8]. After the harvest season, wastewater production is at a minimum and it depends on daily activities [8].

Winery wastewater is high in organic matter from grapes and wine [8,9]. This organic matter contributes up to $85 \%$ of all contaminants in winery wastewater. The remaining organic matter includes yeast, alcohol, esters, sugar, soluble organic acids, tannins, lignin, and polyphenols $[9,13]$. Table 1 presents a summary of conventional wastewater pollutants in winery wastewater, as reported in the literature. In addition to organic matter, nitrogen and phosphorus are of primary concern. Proteins that are removed during stabilization of wine are the predominant source of these nutrients. The use of phosphate detergents can also drastically increase the phosphorus concentrations [14]. Potassium and sodium are often found in high concentrations in winery wastewater due to cleaning agents and excess grape juice [8].

Table 1. Conventional wastewater pollutants in winery wastewater as reported in literature.

\begin{tabular}{|c|c|c|c|c|c|}
\hline Parameter & Unit & Minimum & Maximum & Average & References \\
\hline $\begin{array}{l}\text { Chemical Oxygen } \\
\text { Demand (COD) }\end{array}$ & $\mathrm{mg} / \mathrm{L}$ & 320 & 296,119 & 11,654 & {$[10,13,15-36]$} \\
\hline $\begin{array}{l}\text { Biochemical Oxygen } \\
\text { Demand }\left(\mathrm{BOD}_{5}\right)\end{array}$ & $\mathrm{mg} / \mathrm{L}$ & 125 & 130,000 & 8024 & {$[10,20,24-26,32,34,36]$} \\
\hline Total Solids & $\mathrm{mg} / \mathrm{L}$ & 1602 & 79,635 & 11,311 & {$[20,34,37]$} \\
\hline Total Volatile Solids & $\mathrm{mg} / \mathrm{L}$ & 130 & 54,952 & 4174 & {$[19,20,24,34]$} \\
\hline Suspended Solids & $\mathrm{mg} / \mathrm{L}$ & 60 & 30,300 & 1435 & $\begin{array}{c}{[10,15,16,19,20,22,24,25,29} \\
30,32-34,36]\end{array}$ \\
\hline $\mathrm{pH}$ & - & 3.0 & 12.9 & 5.3 & $\begin{array}{c}{[13-16,19-22,24,25,27,28,30} \\
32-36]\end{array}$ \\
\hline Total Kjeldahl Nitrogen & $\mathrm{mg} / \mathrm{L}$ & 0 & 415 & 110 & {$[20,24,28,34]$} \\
\hline Total Nitrogen & $\mathrm{mg} / \mathrm{L}$ & 10 & 415 & 118 & {$[10,15,19,24,29,32-34,36,38]$} \\
\hline $\begin{array}{l}\text { Ammonia Nitrogen } \\
\left(\mathrm{N}-\mathrm{NH}_{3}\right)\end{array}$ & $\mathrm{mg} / \mathrm{L}$ & 0.001 & 21.1 & - & {$[10,29,36]$} \\
\hline Phosphorus & $\mathrm{mg} / \mathrm{L}$ & 3.3 & 188.3 & 39.5 & {$[10,19,20,24,25,29,33,34,36]$} \\
\hline Sodium & $\mathrm{mg} / \mathrm{L}$ & 7 & 470 & 204 & {$[14,20]$} \\
\hline Potassium & $\mathrm{mg} / \mathrm{L}$ & 29 & 353 & 201 & {$[14,20]$} \\
\hline
\end{tabular}

Without proper treatment, the discharge of winery wastewater can result in adverse health and environmental consequences, such as methemoglobinemia in infants [39], eutrophication, cyanobacterial blooms [40], and cyanotoxins [41]. Metal mobilization is an additional environmental concern when wastewater is treated while using land application. Naturally occurring metals in the soil may become chemically reduced as oxygen becomes depleted during microbially mediated oxidation-reduction reactions [42]. Metals in the soil, such as manganese and iron, are water-soluble when chemically reduced, which allows for groundwater contamination [42].

Regulations have been set to mitigate the impacts of wastewater discharges, and new, more restrictive regulations are driving the development of technologies for winery wastewater treatment $[6,43,44]$. Many wineries are located rurally and they do not have access to public sewers. 
Those that do often face high surcharges due to the acidic $\mathrm{pH}$ and high COD in the wastewater $[6,13]$ make onsite treatment an attractive alternative. Historically, onsite treatment of winery wastewater at small wineries has been accomplished by land application [6], but stricter regulations have increased the land that is needed for treatment, reducing that available for vineyards. Currently, activated sludge systems represent the majority of treatment systems at European wineries [6], but they are complex to operate for small wineries and are expensive due to high energy use [7,9]. Emerging treatment systems for winery wastewater include membrane bioreactors, jet-loop activated sludge, and air micro-bubble reactors, as summarized in Mosse et al. (2011) [9]. However, these technologies may not be applicable to small-scale wineries due to their cost, complexity, and limited demonstrated applications [9].

Further, the high variability in strength and volume of winery wastewater is challenging for small-scale wineries that treat their wastewater onsite in order to meet regulations. Northern wine regions, such as Michigan, face the additional challenge of maintaining treatment during cold winter months. For these reasons, it is necessary to develop a low cost, low complexity treatment system that requires less treatment area than traditional land application methods. The treatment system must also be able to handle the high strength and irregular production of winery wastewater, as well as maintain treatment performance during cold weather.

Subsurface vertical flow constructed wetlands (SVFCWs) have been previously used to treat diverse, high strength wastewater $[45,46]$. In a prior study in our laboratory, SVFCWs were used to biologically treat wastewater in three subsurface gravel cells, where a layer of soil above the SVFCW prevented freezing conditions [47]. An extensive pretreatment system that included a septic tank and an effluent filter mitigated issues that were related to bed clogging [47]. Following pretreatment, wastewater was distributed into the system at the vegetated surface during warm months or below the soil layer during cold months [47]. All of the microbial processes occurred within the lined cells, this preventing metal mobilization. Microbial processes are the main treatment mechanism in SVFCWs, which presents some challenges. During the start-up period of the SVFCW, or after an extended period of no wastewater inflow, nitrogen might not be entirely removed, as nitrifying bacteria grow at much slower rates than heterotrophic bacteria [48]. Additionally, it has been shown that vertical flow wetlands do not significantly remove phosphorus [49].

Previous research on SVFCWs indicates its applicability in treating the organic matter in winery wastewater. However, additional treatment using adsorption media might be required to continuously remove nitrogen and phosphorus during cold weather and after periods of low or no flow of wastewater. Recent research has shown promising results for this type of wastewater for the sorption of ammonia while using the natural zeolite mineral, clinoptilolite [50], and nitrate using tire chips [51]. Sorption allows for the removal of these nutrients, while microbial communities build up and become adequate to treat the nitrogen completely; during periods of low flow of wastewater through the media, these inexpensive materials can be microbially regenerated in-place, which allows for its continued use [51-53]. Additionally, oyster shells with a composition of $95 \%$ calcium carbonate [54] are added to provide $\mathrm{pH}$ buffering [51]. In a prior study, scrap tire chips (1-1.5 cm particle size) were found to leach small amounts of bioavailable organic carbon that supported denitrification [51]. Although low concentrations of zinc, selenium, manganese, antimony, and cobalt were detected, other metals of concern were below the detection limits (see Krayzelova et al. [51] for a review of toxicology studies). Moreover, tire chips have been approved for use in onsite drain field applications in several states [55]. Engineered nano-enhanced media are becoming commercially available to adsorb phosphorus and they can be easily regenerated, and the phosphorus recovered as a fertilizer. For this research, PO4Sponge, by MetaMateria Technologies, Columbus, $\mathrm{OH}$, was used. This adsorption media is a nano-enhanced iron foam that is composed of iron oxide nanocrystals of oxyhydroxide. Its alumino-silicate bonded porous structure gives it increased porosity and contact time, high adsorption rates, and an adsorption capacity ranging from $20-50 \mathrm{mg}$ phosphorus/g media [56].

This research investigates the utility of an SVFCW with nitrogen and phosphorus adsorption media to treat winery wastewater. Performance data were collected from bench-scale treatment 
systems under normal operating conditions, in reduced temperatures, and after periods of no-flow of wastewater.

\section{Materials and Methods}

This project consisted of two studies to assess the utility of an SVFCW and adsorption media in treating winery wastewater. A six-month column study (Carbon and Nitrogen Removal Study) investigated the use of an SVFCW and nitrogen adsorption media to treat winery wastewater under various conditions. The use of PO4Sponge to remove the total phosphorus from treated effluent was assessed in a one-month Phosphorus Removal Study. The plants were not investigated in this project, as plants do not continuously take up nutrients during cold winter months. During summer months, plants assist treatment by increasing oxygen diffusion into the root zones [57]. Additionally, the subsurface application of the wastewater used during cold weather is below the root zone of most wetland-style plants $[47,57]$. As such, it was determined that excluding plants and only investigating the biofilter portion of the constructed wetland would result in the most conservative experimental design.

\subsection{Wastewater}

Wastewater was collected on two separate occasions during the harvest and crush period from a small winery in central Michigan. This winery produces both red and white wine, totaling approximately 2400 cases per year. Process water from the winery is separate from domestic effluent and it was collected from a sampling maintenance hole that was located upstream of a septic tank. The winery wastewater was contained in 19-L (5-gallon) carboys and stored at approximately $4{ }^{\circ} \mathrm{C}$, allowing for the wastewater to remain cold but not frozen. Critical wastewater water quality parameters, including COD, total nitrogen, and total phosphorus, were monitored to ensure relatively consistent influent quality. Supplemental nutrients were added to the wastewater when a key parameter deviated far from the average value. COD and ammonia were observed to degrade the most during storage. These were supplemented with glucose and ammonium chloride, respectively. Table 2 summarizes influent concentrations of critical parameters. A random wastewater sample was analyzed for biochemical oxygen demand $\left(\mathrm{BOD}_{5}\right)$ and it was found to have a $\mathrm{COD}$ : $\mathrm{BOD}_{5}$ ratio of 1.57 . This ratio is within the range of 1.45-1.76, as described by Table 1, and a review paper by Mosse et al. (2011) [9], which indicated that the wastewater that was used in this study was representative of typical winery wastewater. However, it is important to note that concentrations in the wastewater are lower than the average values typically reported in the literature (Table 1). However, these values are consistent with those that were published in a study commissioned by the Michigan Department of Rural and Agricultural Development, which examined five Michigan wineries and also reported higher wastewater to wine ratios [58]. The lower concentrations and higher flows are hypothesized to be caused by more relaxed water management practices in Michigan.

Table 2. Influent wastewater characteristics.

\begin{tabular}{ccccc}
\hline Parameter & Units & Minimum & Maximum & Mean \\
\hline COD & $\mathrm{mg} / \mathrm{L}$ & 2780 & 8110 & 5810 \\
Total Phosphorus & $\mathrm{mg} / \mathrm{L}$ & 14.0 & 44.0 & 21.5 \\
Total Nitrogen & $\mathrm{mg} / \mathrm{L}$ & 12.2 & 58.5 & 33.3 \\
Ammonia Nitrogen & $\mathrm{mg} / \mathrm{L}$ & 3.6 & 29.1 & 13.7 \\
Nitrate Nitrogen & $\mathrm{mg} / \mathrm{L}$ & 0.9 & 27.1 & 4.2 \\
$\mathrm{pH}$ & - & 4.3 & 6.0 & 4.9 \\
\hline
\end{tabular}




\subsection{Carbon and Nitrogen Removal Study}

\subsubsection{Experimental Design}

Four parallel bench-scale wetland systems, each with three columns, were used in the Carbon and Nitrogen Removal Study. Each wetland system simulated an SVFCW, and each column represented a cell. The first cell was the Roughing Cell, the second was the Denitrification Cell, and the third was the Polishing Cell. Generally, the final cell is not required for acceptable treatment in a SVFCW, but it is included to provide operational flexibility in a full-scale system and remove the residual carbon and nitrogen. Only the surface area of the cells was scaled down, resulting in 1.2-m (four-foot) tall columns with the inlet $0.45 \mathrm{~m}$ (1.5 feet) below the top of the column (representing ground level). The diameter of the columns was scaled down to $10.16-\mathrm{cm}$ (four-inches); prior studies have shown that column to particle diameter ratios should be at least 10 to minimize the wall effects [59].

Influent winery wastewater from a settling tank was pumped to an elevated reservoir and then flowed via gravity into the first column of each system through a barbed inlet fitting, $0.45 \mathrm{~m}$ (1.5 feet) below the top of the column. This column was open to the atmosphere, passively aerated, and assumed to be aerobic [60-62]. The effluent wastewater from the first column was then either pumped back into the inlet of the first column (recycled) or into the bottom of the second column. The recycling ratio was maintained at 3:1, with three times the hydraulic load going into the first column as the second. Filling the second column from the bottom resulted in water saturation; therefore, it was assumed that an anoxic environment developed within the second column due to aerobic microbial activity near the inlet. Effluent wastewater from the second column was then pumped to the top inlet of the third column. This column served as a polishing column and it was also open to the atmosphere, passively aerated, and assumed to be aerobic. Treated effluent wastewater flowed out of the bottom of the third column into a capped collection bottle to minimize the potential re-aeration of the effluent before analysis. Figure 1 shows a single wetland system.

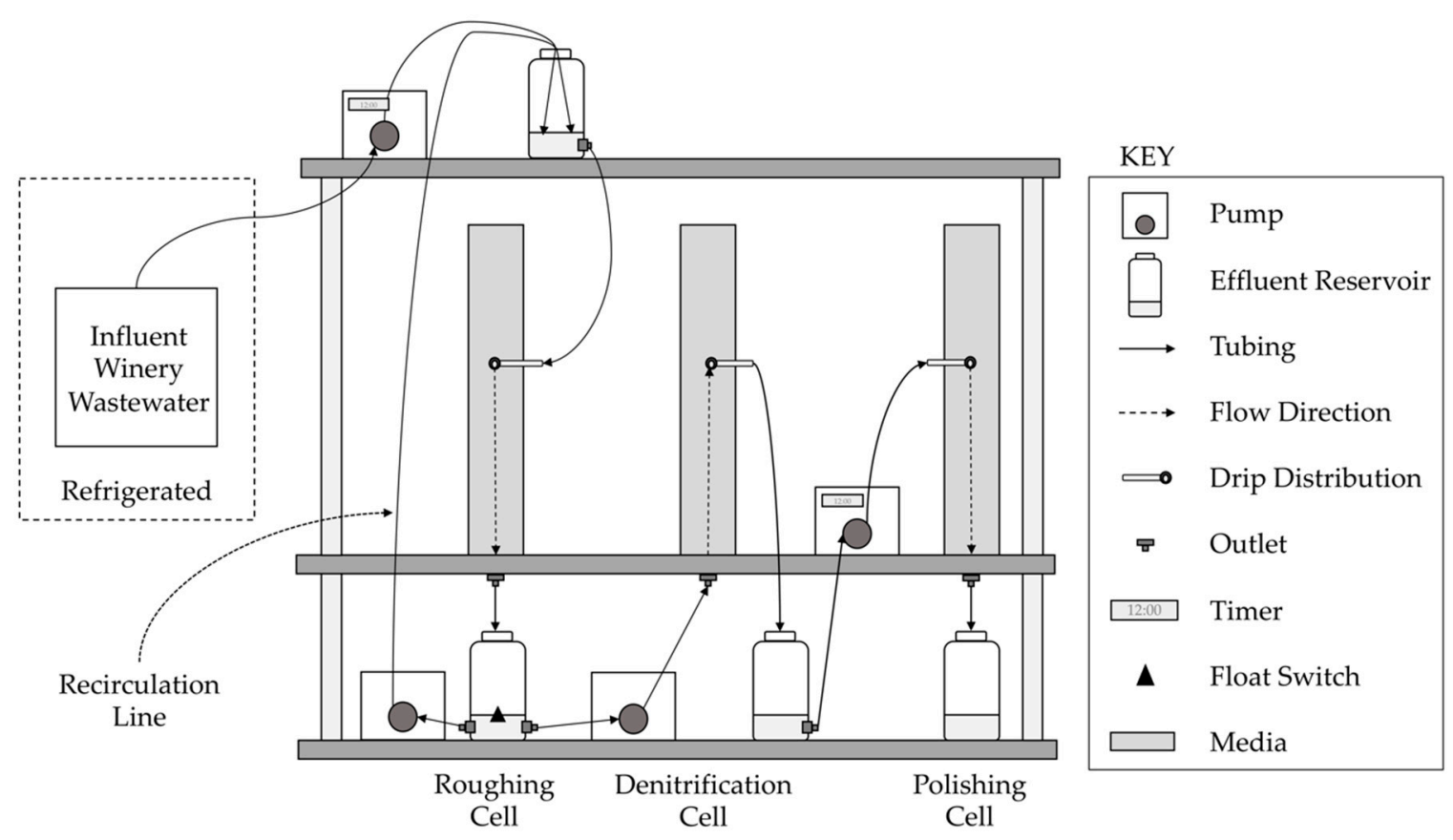

Figure 1. Bench-scale experimental subsurface vertical flow constructed wetland (SVFCW) system.

\subsubsection{Media}

The first system served as the control for determining the impact of nitrogen adsorption media and contained only gravel, which was approximately $0.64-\mathrm{cm}(0.25$-inch) in diameter. The second system (Treatment 1) had clinoptilolite (sieved to 1.18-2.36 mm diameter) and gravel that were mixed 
into the first column and only gravel in the second column. The fourth system (Treatment $2 b$ ) replicated the third (Treatment 2a). These systems included clinoptilolite and gravel in the first column and tire chips (hand-sorted to a particle size of 1-1.5 cm), oyster shells (sieved to 1.18-2.36 mm), and gravel in the second column. The third column of each system was a polishing column with only gravel present. A 3.8-cm (1.5-inch) layer of river rock, approximately 1.9-cm (0.75-inches) in diameter, at the bottom of each column kept the gravel from blocking the bottom inlet/effluent hose barb. The adsorption media was only included in the column between the inlet/effluent hose barbs and it was mixed with gravel before packing to ensure consistent distribution. Table 3 summarizes the media in each system and column.

Table 3. Media in each treatment column.

\begin{tabular}{cccc}
\hline Treatment System & Column 1 & Column 2 & Column 3 \\
\hline Control & Gravel & Gravel & Gravel \\
Treatment 1 & Gravel, clinoptilolite & Gravel & Gravel \\
Treatment 2a & Gravel, clinoptilolite & Gravel, tire chips, oyster shells & Gravel \\
Treatment 2b & Gravel, clinoptilolite & Gravel, tire chips, oyster shells & Gravel \\
\hline
\end{tabular}

The literature indicates that winery wastewater has a high concentration of potassium, which is a competing ion for ammonia removal by clinoptilolite. Although not routinely monitored, potassium concentrations in the wastewater that were used in this study were measured and found to be similar to those reported in the literature (data not reported). As such, the presence of competing ions was accounted for in determining the quantity of clinoptilolite. Rodriguez-Gonzalez [63] observed an adsorption capacity of $11.69 \mathrm{mg} \mathrm{NH}{ }_{4}{ }^{+} \mathrm{N} / \mathrm{g}$ clinoptilolite in the presence of competing ions in an adsorption isotherm study with $100 \mathrm{mg} \mathrm{NH}_{4}{ }^{+}-\mathrm{N} / \mathrm{L}$ and $5 \mathrm{mg} \mathrm{K}^{+} / \mathrm{L}$. This adsorption capacity, influent ammonia concentrations, and an expected microbial start-up period of 14 days [63] were used to calculate the amount of clinoptilolite that was added to the treatment columns. The mass of tire chips and oyster shells was determined based on influent concentrations, adsorption isotherm studies that were conducted by Krayzelova et al. (2014) [51], and also assumed a 14-day start-up period. The addition of oyster shells was based on a mass ratio of tire chips to oyster shells of 250:13 [51]. Table 4 details the volumetric factions of media added to the treatment columns.

Table 4. Fraction of media added by volume.

\begin{tabular}{ccc}
\hline Treatment Column & Material & Mass Fraction \\
\hline \multirow{2}{*}{ Treatments 1, 2a, and 2b Column 1 } & Gravel & 0.988 \\
& Clinoptilolite & 0.012 \\
\hline \multirow{2}{*}{ Treatments 2a and 2b Column 2 } & Gravel & 0.965 \\
& Tire Chips & 0.034 \\
& Oyster Shells & 0.001 \\
\hline
\end{tabular}

\subsubsection{Inoculation}

Each column was inoculated with secondary effluent wastewater before operating the treatment systems. The inoculum was collected from a local wastewater treatment plant that is permitted for maximum weekly and daily effluent carbonaceous $\mathrm{BOD}_{5}$ concentrations of 4 and $9.9 \mathrm{~m} / \mathrm{L}$, maximum monthly and daily effluent ammonia concentrations of 0.27 and $5.03 \mathrm{mg} \mathrm{NH}_{4}-\mathrm{N} / \mathrm{L}$, and maximum monthly total phosphorus concentrations of $0.95 \mathrm{mg} / \mathrm{L} \mathrm{P}$ (NPDES Individual Permit MI0021717 v5.0). The inoculation of the systems was completed by filling each column with the wastewater, holding it within the column for five days, and letting it drain for two days before operation.

An additional test investigated the start-up period for an SVFCW without inoculation. This test used four columns with the same configuration as Column 1 in the Carbon and Nitrogen Removal 
Study; two columns were filled with gravel only, and two columns were filled with gravel and clinoptilolite. These columns were not inoculated before system operation.

\subsubsection{Operating Conditions}

Different operating conditions, or phases, were tested in the Carbon and Nitrogen Removal Study. The first phase was considered to be standard operating conditions. This phase was carried out at room temperature $\left(20^{\circ} \mathrm{C}\right)$ and the wastewater was distributed into the SVFCWs four times per day at $8 \mathrm{am}, 11 \mathrm{am}, 2 \mathrm{pm}$, and $5 \mathrm{pm}$. This schedule was chosen to simulate the frequency of wastewater production at a small winery where wastewater is produced in batches rather than continuously. Wastewater was distributed at an approximate surface loading rate of $5.18 \mathrm{~kg} \mathrm{COD} / \mathrm{m}^{2} / \mathrm{d}\left(1.06 \times 10^{-2}\right.$ $\mathrm{lb} \mathrm{COD} / \mathrm{ft}^{2} / \mathrm{d}$ ); this loading rate was previously determined to be optimum for a cold-weather SVFCW treating milking facility wastewater [45], but had not been tested for winery wastewater. The resulting hydraulic loading rate was $6.87 \mathrm{~L} / \mathrm{m}^{2} / \mathrm{d}\left(0.17 \mathrm{gal} / \mathrm{ft}^{2} / \mathrm{d}\right)$. The resulting hydraulic retention time was approximately two weeks and the saturated column controlled it. The second phase maintained the temperature and surface loading rate of Phase 1 , but the distribution of wastewater was changed to even, 6-h increments throughout the day. The third phase maintained the loading frequency and rate of Phase 2, but reduced the temperature of the system to $10{ }^{\circ} \mathrm{C}$. The start-up test was operated with the same conditions as Phase 2 . The influent wastewater was allowed to settle out solids for a minimum of $24 \mathrm{~h}$ before distribution to the treatment systems in each phase and test.

\subsection{Phosphorus Removal Study}

\subsubsection{Experimental Design}

Phosphorus removal must occur after the SVFCW, so that microbial processes have the phosphorus necessary for the degradation of other nutrients. As such, the phosphorus removal study was designed to simulate a treatment system with a settling tank as primary treatment, the SVFCW as secondary treatment, and PO4Sponge as tertiary treatment. This treatment system design allows for flexibility in full-scale implementation, as the tertiary treatment is easily removed if phosphorus removal is not necessary at a winery.

The Phosphorus Removal Study used 3.8-cm (1.5-inch) diameter columns with a 2.5-cm (1-inch) layer of gravel at the bottom to prevent media washout. One column served as the control and only contained the gravel layer (Control). Two columns contained the gravel layer and PO4Sponge (Test and Replicate). The quantity of PO4Sponge was determined following the manufacturer recommendation for an empty bed contact time of $30 \mathrm{~min}$. for influent concentrations of $10-20 \mathrm{mg} / \mathrm{L}$ total phosphorus [64]. Wastewater was pumped into the top of the columns and directly distributed onto the adsorption media (Figure 2). 


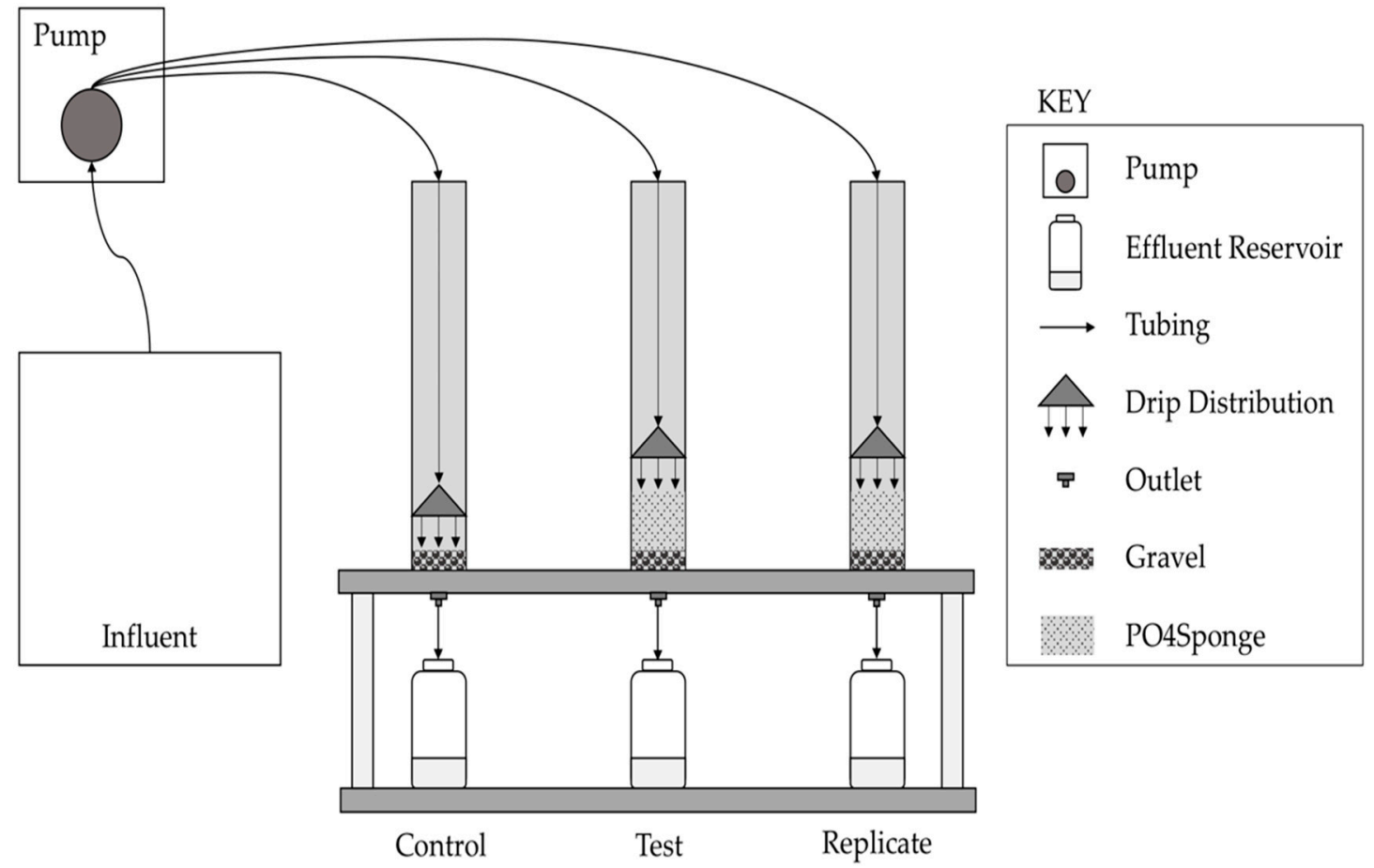

Figure 2. Phosphorus removal experimental design.

\subsubsection{Wastewater}

Treated wastewater from the Carbon and Nitrogen Removal Study was supplemented with monopotassium phosphate to match the average phosphorus concentration of the untreated wastewater to mimic when the SVFCW no longer removes phosphorus via adsorption.

\subsubsection{Operating Conditions}

The Phosphorus Removal Study was carried out for 36 days. This study was conducted at room temperature $\left(20^{\circ} \mathrm{C}\right)$, and the wastewater was distributed into the columns at the same hydraulic loading rate and frequency used in Phase 2 of the Carbon and Nitrogen Removal study. The daily volume of wastewater that was distributed into the columns was equal to that distributed into the SVFCW.

\subsection{Wastewater Sampling and Analysis}

$\mathrm{COD}, \mathrm{BOD}_{5}$, total nitrogen, and total phosphorus are the most relevant parameters for determining treatment system efficiency [6]. A third-party laboratory only measured $\mathrm{BOD}_{5}$ once during the project due to the difficulty and cost of the test. All other parameters, with the addition of ammonia, nitrate, and $\mathrm{pH}$, were measured with every sampling.

The grab samples for each study were collected immediately following wastewater loading into the treatment systems. The samples were refrigerated or tested immediately after collection. If a sample was not tested within $24 \mathrm{~h}$ of collection, it was preserved with concentrated sulfuric acid and tested within 28 days of preservation. A preserved sample was first neutralized with a $5 \mathrm{M}$ sodium hydroxide solution before testing. Testing, preservation, and neutralizing methods followed HACH standard procedures, as summarized in Table 5. All of these methods are compliant with United States Environmental Protection Agency (USEPA) testing standards, with the exception of total nitrogen [65]. 
Table 5. Testing methods.

\begin{tabular}{cccc}
\hline Test & Method & Minimum Detectable Limit & HACH Method \\
\hline Phosphorus, Total (High Range) & Ascorbic Acid & $0.5 \mathrm{mg} / \mathrm{L} \mathrm{PO}_{4}-\mathrm{P}$ & 10,209 \\
\hline Phosphorus, Total (Ultra Low Range) & Ascorbic Acid & $10 \mu \mathrm{gg} / \mathrm{L} \mathrm{PO}_{4}-\mathrm{P}$ & 10,209 \\
\hline COD & Reactor Digestion & $20 \mathrm{mg} / \mathrm{L}$ & 8000 \\
\hline BOD $_{5}$ & $\begin{array}{c}\text { Luminescence } \\
\text { Measurement of } \\
\text { Dissolved Oxygen }\end{array}$ & $3 \mathrm{mg} / \mathrm{L}$ & 10,360 \\
\hline Nitrogen, Total & Persulfate Digestion & $1 \mathrm{mg} / \mathrm{L}$ & 10,208 \\
\hline Nitrogen, Ammonia & Dimethylphenol & $0.2 \mathrm{mg} / \mathrm{L} \mathrm{NO}-\mathrm{N}$ & 10,206 \\
\hline Nitrogen, Nitrate & Salicylate & $1 \mathrm{mg} / \mathrm{L} \mathrm{NH}-\mathrm{N}$ & 10,205 \\
\hline $\mathrm{pH}$ & $\mathrm{pH}$ probe & 1 & Calibrated probe \\
\hline
\end{tabular}

A standard, random replicate, and blank sample were included in the testing for quality assurance and control at an approximate rate of $10 \%$. Table 6 summarizes the percent relative range between replicates of each study and parameter and it is separated by study and parameter. The percent recovery of the tested standards and their supposed value is summarized in Table 7 and is separated by study and parameter.

Table 6. Percent relative range.

\begin{tabular}{ccc}
\hline Test & $\begin{array}{c}\text { Carbon and Nitrogen Removal } \\
\text { Study }\end{array}$ & Phosphorus Removal Study \\
\hline Phosphorus, Total (High Range) & N/A & 1.7 \\
Phosphorus, Total (Ultra Low & N/A & 4.9 \\
Range) & 4.5 & N/A \\
COD & 7.1 & N/A \\
Nitrogen, Total & 5.4 & N/A \\
Nitrogen, Ammonia & 7.2 & N/A \\
Nitrogen, Nitrate & & \\
\hline
\end{tabular}

Table 7. Percent recovery.

\begin{tabular}{ccc}
\hline Test & Carbon and Nitrogen Removal Study & Phosphorus Removal Study \\
\hline Phosphorus, Total (High Range) & N/A & 97.4 \\
Phosphorus, Total (Ultra Low Range) & N/A & 94.3 \\
COD & 97.6 & N/A \\
Nitrogen, Total & 95.5 & N/A \\
Nitrogen, Ammonia & 95.5 & N/A \\
Nitrogen, Nitrate & 99.4 & N/A \\
\hline
\end{tabular}

\subsection{Statistical Analysis}

Statistical analysis was performed while using a repeated measures mixed model procedure in SAS v. 9.4 (SAS Institute Inc., Cary, NC, USA) with the influent concentration as a covariate. The repeated effects included "Days from Start" with "Column" nested within "Treatment" as the subject. Significant treatment effects were defined as $p<0.05$, and the trending treatment effects were defined as $p<0.10$. For significant effects, comparisons were made while using Tukey's post-hoc analysis. 


\section{Results and Discussion}

\subsection{Carbon and Nitrogen Removal Study}

Figure 3 shows the course of the influent and effluent characteristics for each treatment system, including COD, total nitrogen, nitrate, and $\mathrm{pH}$ (plot not included for ammonia as all of the effluent samples were below the detectable limit of $1 \mathrm{mg} / \mathrm{L}$ ).

A Influent - Control $\square$ Treatment $1+$ Treatment $2 \mathrm{a} \otimes$ Treatment $2 \mathrm{~b}$
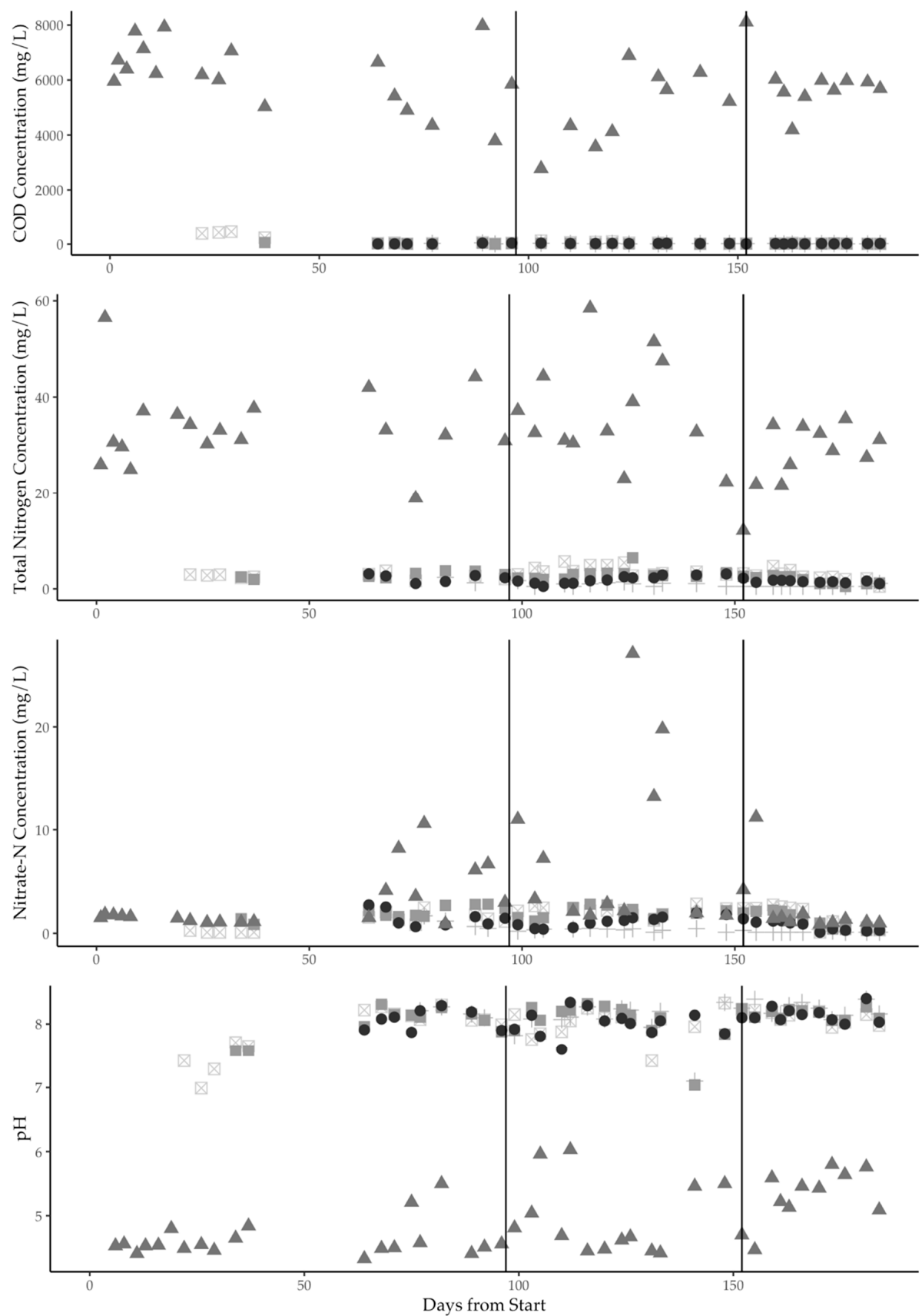

Figure 3. Variation of influent and effluent concentrations in each treatment system. Solid vertical lines separate the three phases. Effluent results below the detectable limit were plotted at half the detectable limit. 


\subsubsection{COD}

The influent concentrations of COD varied throughout the study, but they were generally between 5000-6000 mg/L. Phase 1 had an average influent concentration of $6189 \mathrm{mg} / \mathrm{L}$, Phase 2 was $4997 \mathrm{mg} / \mathrm{L}$, and Phase 3 was $5851 \mathrm{mg} / \mathrm{L}$. Despite the varying influent concentrations, 90\% of all effluent samples were below $50 \mathrm{mg} / \mathrm{L}$, and $33 \%$ were below the detection limit of $20 \mathrm{mg} / \mathrm{L}$. Across all of the treatment systems and phases, over $90 \%$ of the total COD removal occurred in the first column. No significant differences in COD removal were observed between the control system and the treatment systems with the nitrogen adsorption media $(p>0.05)$.

The high level of treatment that was observed throughout the study was consistent with the performance of other configurations of vertical flow constructed wetlands for the treatment of winery wastewater and previous applications of this system in treating milking facility wastewater. In a 2011 study by Serrano et al. (2011) [11], the vertical flow stage of a hybrid constructed wetland was shown to remove up to $70 \%$ COD from winery wastewater. The influent concentrations to the vertical flow stage ranged from 422 to $2,178 \mathrm{mg} / \mathrm{L}$ COD and surface loading rates to this stage ranged from $4.3 \times 10^{-2}$ to $4.66 \mathrm{~kg} \mathrm{COD} / \mathrm{m}^{2} / \mathrm{d}\left(8.78 \times 10^{-3}\right.$ to $\left.9.5 \times 10^{-2} \mathrm{lb} \mathrm{COD} / \mathrm{ft}^{2} / \mathrm{d}\right)$ [11]. Rozema et al. (2016) [46] monitored six years of performance data from a similar system treating winery wastewater that was mixed with domestic wastewater in the cold-weather climate of Ontario, Canada. The system had four subsurface treatment cells that contained a gravel-and-sand mixture with the third cell saturated and containing wood chips to facilitate denitrification. This system had a surface loading rate of $3.4 \times 10^{-2} \mathrm{~kg} \mathrm{COD} / \mathrm{m}^{2} / \mathrm{d}\left(6.96 \times 10^{-3} \mathrm{lb} \mathrm{COD} / \mathrm{ft}^{2} / \mathrm{d}\right)$ and treated an average influent concentration of $3043 \mathrm{mg} / \mathrm{L}$ COD during the six warmest months of the year and $2117 \mathrm{mg} / \mathrm{L}$ COD during the six coolest months of the year. This system consistently removed an average of $99 \%$ COD [46]. In a 2015 study, Campbell \& Safferman (2015) [45] observed 96\% COD removal while using an SVFCW to treat milking facility wastewater with an average influent concentration of $736 \mathrm{mg} / \mathrm{L} \mathrm{COD}$. Although the influent concentration was lower than that used in this study, the treatment systems were sized while using the same surface loading rate of $5.18 \mathrm{e}-2 \mathrm{~kg} \mathrm{COD} / \mathrm{m}^{2} / \mathrm{d}\left(1.06 \times 10^{-2} \mathrm{lb} \mathrm{COD} / \mathrm{ft}^{2} / \mathrm{d}\right)$ [45]. This surface loading rate is the greatest of the discussed systems, which indicated the smallest land area needed for maintaining high treatment efficiency. A review of biological treatment systems for winery wastewater found that COD removal efficiencies are generally within 90-95\% of total COD due to the recalcitrant soluble fraction of COD that cannot be biologically or physically removed [66].

Biological removal is a main method of COD removal in constructed wetlands [57]. Treatment systems are commonly inoculated before operation to decrease the start-up time of the microbial populations $[67,68]$, as was done in this study. Even with inoculation, a start-up period of approximately 13 days was required for each treatment system to reach $>90 \%$ removal efficiency. The first column of the systems was operated without prior inoculation to investigate the role of inoculation in the start-up period.

Figure 4 illustrates the COD removal efficiency over time for columns that were inoculated and those that were not inoculated before operation. The removal efficiency was higher than in the columns that were not inoculated in the first 13 days of the start-up period for the inoculated columns. However, by the thirteenth day, both sets of columns had reached $>90 \%$ COD removal efficiencies. The similar start-up periods indicate that there is an active microbial community present in the winery wastewater that is capable of colonizing the media, as corroborated by Malandra et al. (2003) [13]. Inoculation with wastewater biomass only slightly increases the treatment efficiency during the start-up period. 


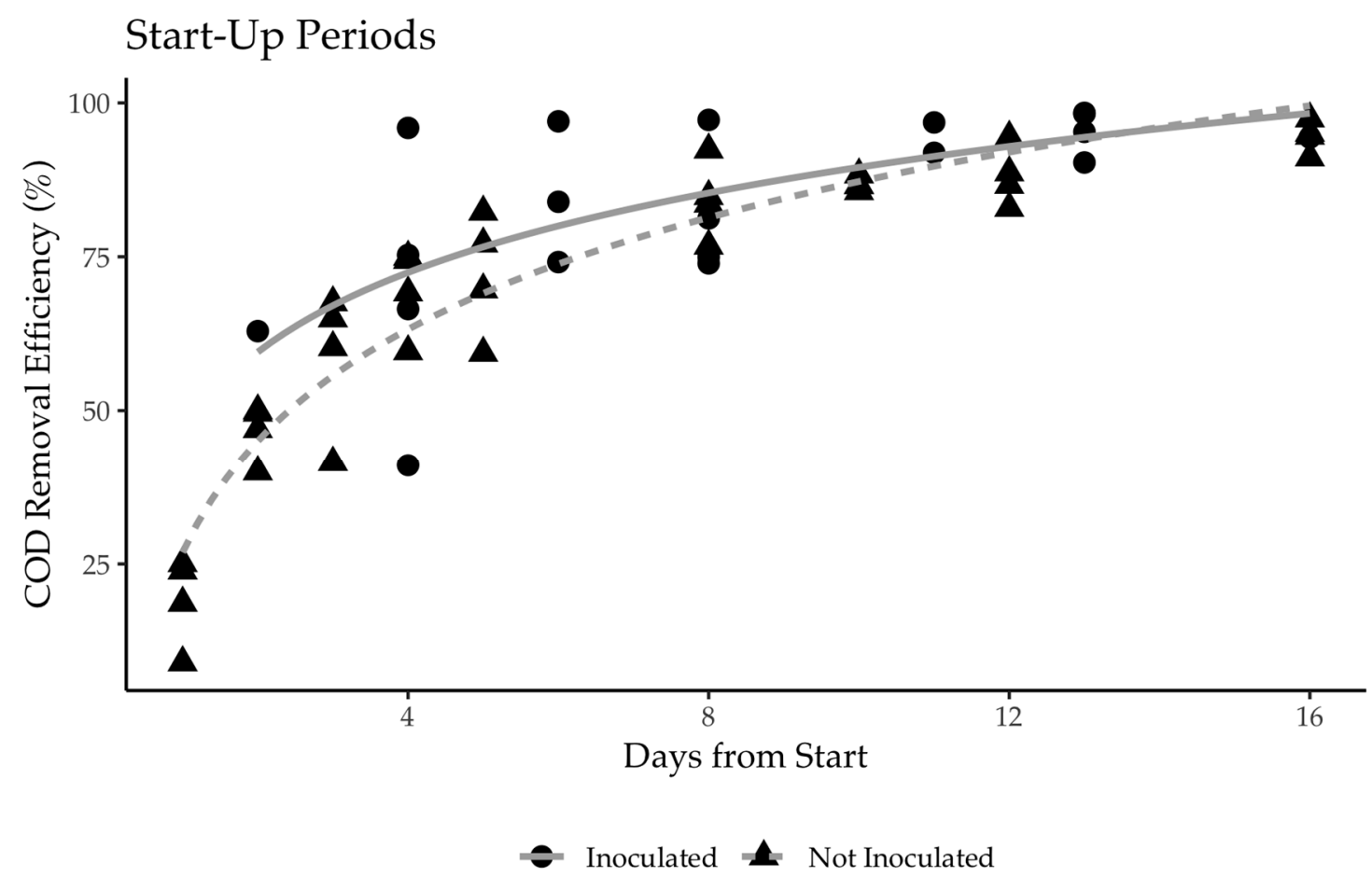

Figure 4. Variation of the chemical oxygen demand (COD) removal efficiency during the start-up period with column inoculated and not inoculated prior to operation.

The durations for the start-up period that were observed in this study align with those previously reported in the literature. In winery wastewater treatment, a start-up period of ten days has been observed for aerated lagoons, sequencing batch reactors, and membrane bioreactors $[27,67,68]$. Without inoculation, the aerated lagoon exhibited removal within the first ten days of operation and reached $>90 \%$ by the 21st day of operation [27]. The first aggregates were observed in the sequencing batch reactor [68], and a removal efficiency of $97 \%$ was expressed for the membrane bioreactor [67] after inoculation and ten days of operation.

Changing the frequency of loading from four times between 8 am and $5 \mathrm{pm}$ to loadings every six hours did not significantly impact the performance of the treatment systems. Similarly, treatment during the reduced temperature phase was not significantly different, showing that the surface loading rate of $5.18 \mathrm{~kg} \mathrm{COD} / \mathrm{m}^{2} / \mathrm{d}\left(1.06 \times 10^{-2} \mathrm{lb} \mathrm{COD} / \mathrm{ft}^{2} / \mathrm{d}\right)$ was appropriate for treatment during reduced temperatures. These results are consistent with other studies that used vertical flow constructed wetlands with different waste streams, including domestic wastewater [49], milking facility wastewater [45], and winery wastewater [46].

\subsubsection{Nitrogen}

Total nitrogen removal occurs through microbial metabolic processes in classical wastewater treatment processes. Organic nitrogen is first mineralized to ammonia, which is then nitrified to nitrite and nitrate under aerobic conditions. Under anoxic conditions, the nitrate is denitrified to nitrogen gas [69]. Generally, $\mathrm{pH}$ decreases with nitrification and increases with denitrification [70].

Throughout this study, influent concentrations of total nitrogen varied, with average influent concentrations in Phases 1, 2, and 3 of $33.8 \mathrm{mg} / \mathrm{L} \mathrm{N}, 37.2 \mathrm{mg} / \mathrm{L} \mathrm{N}$, and $27.7 \mathrm{mg} / \mathrm{L} \mathrm{N}$, respectively. Despite this variation, influent concentration did not greatly influence the system performance. An average of $72 \%$ of total nitrogen removal occurred within the first column of each system during Phase 1,78\% during Phase 2, and $85 \%$ during Phase 3. Except for Treatment $2 \mathrm{~b}$, each system exhibited $>90 \%$ overall removal of total nitrogen across all phases; Treatment $2 \mathrm{~b}$ had an average removal of $88 \%$ and $89 \%$ in 
Phases 2 and 3, respectively. Across all the systems and phases, $97.5 \%$ of final effluent values were below $5 \mathrm{mg} / \mathrm{L}$, and treatment under cool conditions was not significantly different.

Ammonia was removed entirely and immediately by the first column of every system to a concentration that was below the detection limit of $1 \mathrm{mg} / \mathrm{L} \mathrm{NH}_{3}-\mathrm{N}$. This high level of treatment was exhibited, regardless of the influent concentration, which averaged $14.6 \mathrm{mg} / \mathrm{L} \mathrm{NH}_{3}-\mathrm{N}$ in Phase 1, 12.7 $\mathrm{mg} / \mathrm{L} \mathrm{NH}_{3}-\mathrm{N}$ in Phase 2, and $11.5 \mathrm{mg} / \mathrm{L} \mathrm{NH} 3-\mathrm{N}$ in Phase 3, and spiked as high as $29 \mathrm{mg} / \mathrm{L} \mathrm{NH} \mathrm{N}_{3}-\mathrm{N}$. This complete removal with no observed lag period was also observed in the columns that had not been inoculated in the Start-Up test. In the Control, Treatment 1 , and Treatment $2 b$ systems, the second column exhibited detectable levels of ammonia in Phases 2 and 3. This release of ammonia was hypothesized to be a result of organic nitrogen ammonification due to heterotrophic degradation within the column. These levels were not concerning, as they were always below $4 \mathrm{mg} / \mathrm{L}$ and were always removed to concentrations below the detectable limit in the third column.

As all effluent ammonia concentrations were below detectable limits, there was no statistical difference during reduced temperatures or between the treatment systems with and without clinoptilolite. These results are in contrast with prior work, showing that the addition of natural zeolite materials to an ammonia-rich solution (1000 $\left.\mathrm{mg} \mathrm{NH}_{4}{ }^{+}-\mathrm{N} / \mathrm{L}\right)$ reduced free ammonia inhibition and increased nitrification rates [71]. The addition of adsorptive media might provide an advantage in systems operated at higher nitrogen loading rates. The high concentrations of potassium in winery wastewater may also have impacted ammonia removal, as clinoptilolite is known to have a higher affinity for potassium than ammonium when the two ions are present in equimolar concentrations. However, when ammonium concentrations are higher than potassium, this effect is reduced, as was observed in a 2017 study that demonstrated $80-90 \%$ ammonia removal efficiency by clinoptilolite when treating swine wastewater with a $\mathrm{NH}_{4}{ }^{+}$concentration of $54 \mathrm{M}$ and a $\mathrm{K}+$ concentration of 3.0 $\mathrm{M}$ [72]. Consequently, more research is needed to better understand the impact of potassium and other competing ions in winery wastewater.

It is generally accepted that ammonia removal in constructed wetlands is a result of biological degradation, plant uptake, volatilization, and adsorption to bed media [57]. In this study, plants were not included, and volatilization can be largely neglected due to the acidic $\mathrm{pH}$ of the wastewater [73]. Although gravel can serve as an adsorption media for ammonia [74], this removal mechanism can be discounted in this study due to detectable levels of ammonia in the effluents of the second column of the Control, Treatment 1 , and Treatment $2 \mathrm{~b}$ in Phase 2. It is unlikely that these detectable concentrations were a result of ammonia breakthrough, as there was never any detectable concentrations of ammonia going into the second columns. If able to be adsorbed, any ammonia mineralized in the column would have been adsorbed onto the gravel and would not have been present in the effluent, as observed.

Influent concentrations of nitrate fluctuated widely throughout the study, which resulted in varying effluent concentrations. Effluent concentrations never exceeded $2.75 \mathrm{mg} / \mathrm{L} \mathrm{N}$, despite the variability. There was not a significant difference in nitrate removal between systems with and without tire chips for nitrate adsorption. The treatment performance was significantly better during Phase 3 than Phase 1 in the Control system. In the rest of the systems, there was not a significant difference in performance between phases. The second column in each system exhibited the highest removal across all systems and phases, reducing nitrate by an average of $92 \%, 93 \%$, and $87 \%$ in Phases 1, 2, and 3 , respectively. This phenomenon was expected due to the saturated conditions in the columns that promoted denitrification. Unexpectedly, nitrate was also immediately removed in the first column of each system, which indicated that both aerobic and anoxic zones were present in the columns or biofilms. This immediate removal was also observed in the Start-Up test, where the columns were not inoculated.

After the Start-up period, a majority of the samples (76\%) during Phase 1 were collected at the morning loading period after the system had rested for $15 \mathrm{~h}$. The remaining samples were collected during the evening loading period to verify consistency. The observed concentrations were not substantially different between the morning and evening samples (data not shown). These results 
are in contrast to previous studies, where higher nitrate and lower ammonium concentrations were observed in the morning samples [50].

Figure 5 shows the average nitrogen transformations in the wastewater through each column of each system in Phase 1. Organic nitrogen was calculated by subtracting ammonia and nitrate from total nitrogen, assuming no other forms of inorganic nitrogen were present with the given operating conditions and influent ammonia concentrations [71,75].

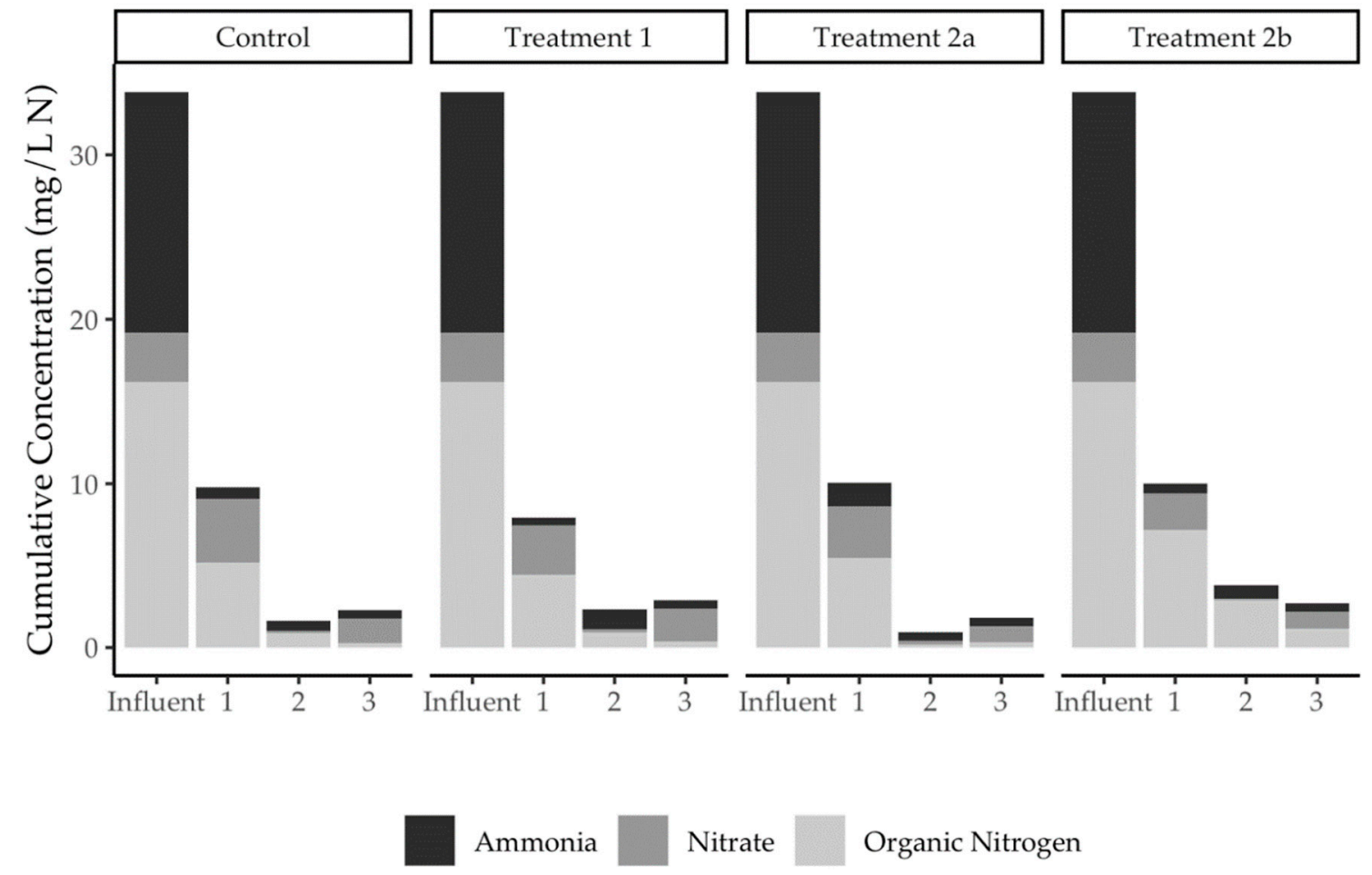

Figure 5. Total nitrogen removals and nitrogen transformations in the treatment systems.

The largest differences in total nitrogen removal were observed in systems Treatment 2a and Treatment $2 b$, which was unexpected, as both systems had the same initial construction and operation. However, Treatment 2a consistently performed better than the other systems, which suggested that the nitrogen adsorption media might have enhanced performance. The high nitrogen removal of all the treatment systems, regardless of nitrogen adsorption media, is likely explained by the favorable COD:N:P ratio of winery wastewater of 270:1.5:1. Several review papers on biological treatment of winery wastewater have cited the imbalance of COD:N:P as an impediment for carbon removal, with nitrogen and phosphorus as the limiting nutrients $[6,66,76]$. The ratio of COD:N in winery wastewater is often 100, an order of magnitude larger than that in municipal wastewater [6,77]. As such, nitrogen and phosphorus are expected to have higher removal efficiencies as microbes use up these nutrients for biosynthesis. A high C:N ratio is favorable for denitrification [78]; however, it might inhibit nitrification processes [76]. In a study of three constructed wetlands operating in Italy, it was found that total nitrogen removal was greater when the organic substrate concentrations were higher [79], emphasizing the vital role that the C:N ratio plays in the biological treatment of winery wastewater.

\subsection{3. $\mathrm{pH}$}

The average influent $\mathrm{pH}$ for Phases 1,2, and 3 was 4.62, 4.97, and 5.30, respectively. These values are consistent with those found in literature, as shown in Table 1 . There was not a significant difference in the effluent $\mathrm{pH}$ between treatment systems, with and without oyster shells as a $\mathrm{pH}$ buffer. The effluent from Column 1 averaged 7.10, 7.17, and 7.00 in each phase. This wastewater was recirculated and mixed with raw winery wastewater, which helps to neutralize the $\mathrm{pH}$ before distribution into 
Column 1. The average effluent from the third column for each phase was $8.04,8.09$, and 8.17. The increase in $\mathrm{pH}$ with both nitrification and denitrification aligns with the findings by Malandra et al. (2003) [13], who found that $\mathrm{pH}$ increased with a decrease in COD by metabolic processes of microbes naturally occurring within winery wastewater. While oyster shells were not needed in this study, oyster shells might be useful as a source of alkalinity in the nitrification stage of biofilters treating low alkalinity wastewaters, because nitrification consumes alkalinity.

\subsection{Phosphorus Removal Study}

The results of the PO4Sponge performance were consistent with previous studies in removing total phosphorus concentrations down to low levels [56]. The control column, which only had a $2.5-\mathrm{cm}$ (1-inch) layer of gravel, did not remove a significant amount of phosphorus (Figure 6A). The columns with PO4Sponge removed high levels of total phosphorus $(17.55 \mathrm{mg} / \mathrm{L} \mathrm{P})$ to concentrations of less than $0.102 \mathrm{mg} / \mathrm{L}$ P. In $84 \%$ of the treated samples, the effluent concentrations were less than or equal to 0.06 $\mathrm{mg} / \mathrm{L} \mathrm{P}$ (Figure 6B). It is not known why there was an initial increase in phosphorus removal by the PO4Sponge; however, the higher levels at the beginning of the study were not concerning, as they were still quite low. These results show that components in SVFCW treated winery wastewater do not impact the performance of PO4Sponge and that loading the wastewater from the top does not reduce the adsorption media performance. Consistent performance, regardless of the direction of wastewater flow, allows for flexibility in the full-scale design and implementation of this treatment system. Following treatment, the phosphorus can be removed from the PO4Sponge by precipitation and used for beneficial purposes.

(A)

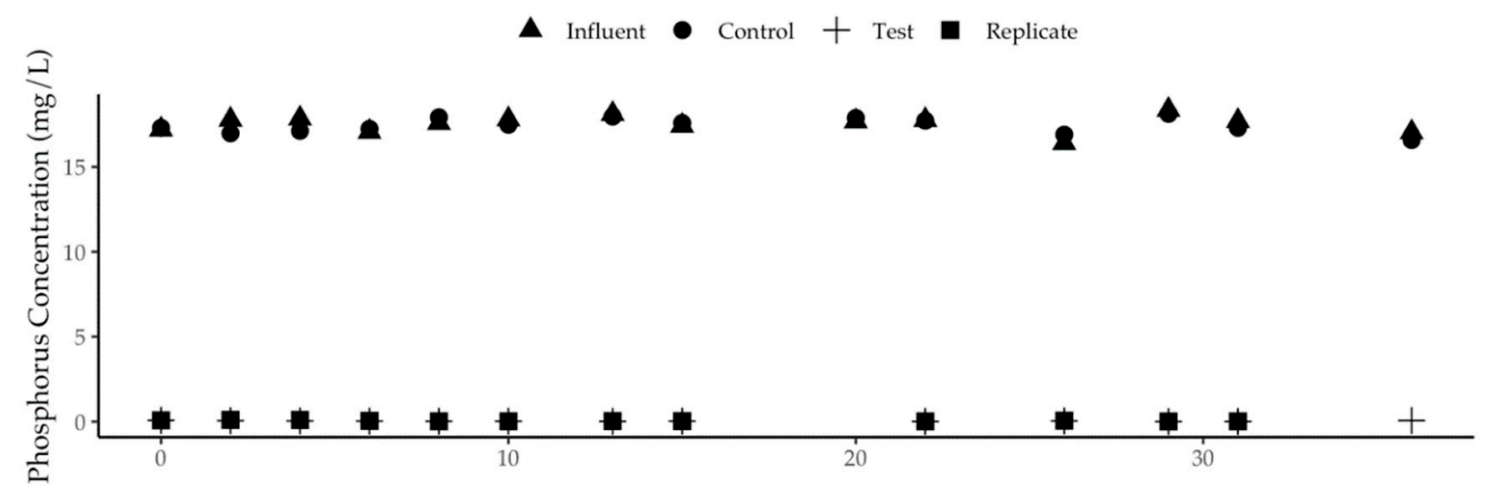

(B)

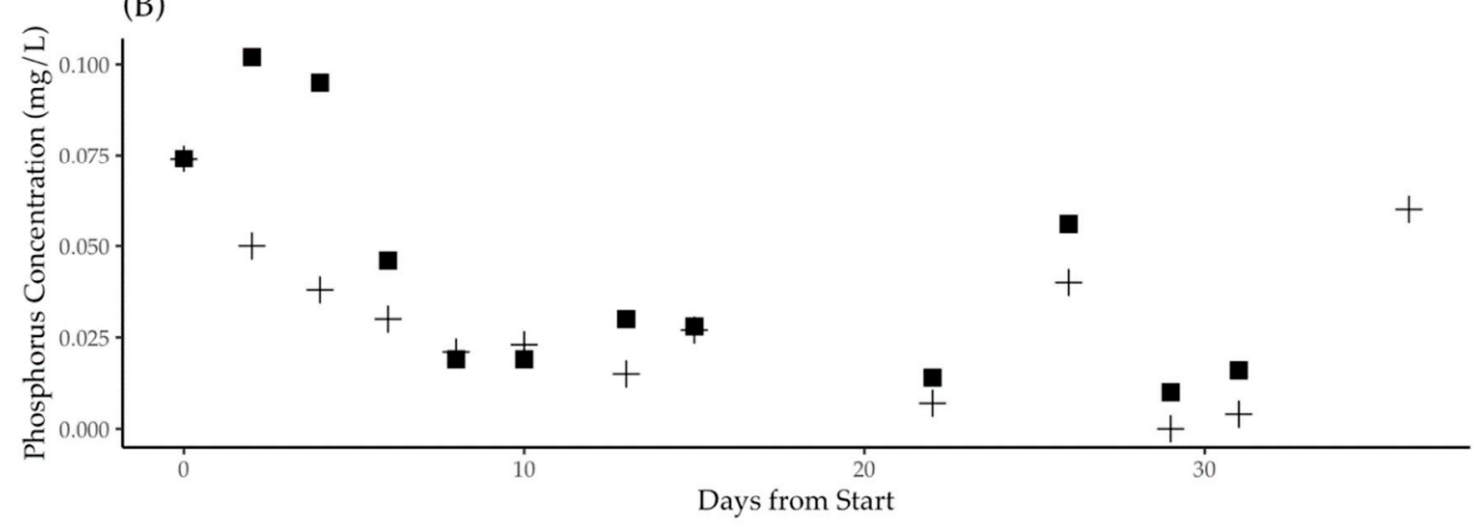

Figure 6. (A) Variation of influent and effluent concentrations of phosphorus in the control and treatment systems. (B) Rescaled plot (A) showing effluent concentrations of phosphorus in the treatment systems. 


\section{Conclusions}

The bench-scale SVFCW shows the potential to sufficiently treat winery wastewater under variations in loading rates, frequency, and temperature without the aid of nitrogen adsorption media or a $\mathrm{pH}$ buffer. Although this contradicts the original hypothesis that a SVFCW would not provide sufficient treatment without amendments, this represents a more cost-effective solution for small-scale industrial wineries. The bench-scale systems in this study demonstrated removal efficiencies for COD of $>99 \%$ under constant loading frequencies and room temperature and with decreased temperatures. Removal efficiencies of $95 \%$ and $94 \%$ for total nitrogen were observed for constant loading frequencies with room temperature and decreased temperatures, respectively. The effluent concentrations were considerably better than the quality of septic system effluent, allowing for versatility in the final discharge of the treated wastewater.

This treatment system is advantageous to other conventional treatment methods due to its minimal surface area requirements, low energy demands, and high treatment performance. SVFCWs require approximately $80 \%$ less treatment area than land application, using the permitted Michigan surface loading rate of 50 pounds of $\mathrm{BOD}_{5} /$ acre/day [80] for land application as an example. In addition to the potential economic benefit from the sale of wetland plants [81], the use of aesthetically pleasing vegetation might be beneficial to wineries where tourism is important. Additionally, SVFCWs are substantially more energy-efficient than activated sludge [7]. Further, the characteristics of the discharged wastewater from SVFCWs are comparable to or better than wastewater treated by conventional methods, such as activated sludge [82]. These benefits make this technology a viable option for implementation at small-scale industrial wineries. The increased effectiveness of the addition of nitrogen adsorption media was unclear and should be further examined with a waste stream that has a more favorable C:N:P ratio. This study demonstrated that nitrogen adsorption media is not required for effective treatment of winery wastewater while using an SVFCW, but that it might enhance SVFCW treatment of wastewaters with higher nitrogen concentrations. The inclusion of the phosphorus adsorption media, PO4Sponge, was found to be an effective means of removing total phosphorus from winery wastewater to concentrations below $0.102 \mathrm{mg} / \mathrm{L}$. Further study is needed for determining the capacity of the PO4Sponge for winery wastewater to better understand the frequency of replacing the media. However, research on other waste streams has demonstrated a media adsorption capacity of 50 mg P per gram of media with an initial phosphorus level of $7 \mathrm{mg} / \mathrm{L}$ [83]. Additionally, other engineered adsorption media are commercially available, and waste material formulated into adsorption media, such as steel furnace slag, should be evaluated to determine which is best suited for application at a winery [84].

A field demonstration is needed to monitor performance in a diverse environment, determine any additional design and operational considerations, and verify whether clogging will become an issue over time. A previous field study of a similarly designed SVFCW treating milking facility wastewater observed no clogging over five years of monitoring [45]. These observations are consistent with this study, which also did not detect clogging. However, a six-month study is not indicative of the expected performance of a twenty-year treatment system [57], and further research is needed. Additionally, this application was focused in a region where combining domestic wastewater with industrial wastewater is strongly discouraged. However, domestic wastewater could provide a year-round source of substrate to microbial communities in regions where co-treatment is allowed, justifying further investigation.

Author Contributions: Conceptualization, S.I.S. and S.J.E.; methodology, K.S., L.R.-G., S.J.E.; formal analysis, K.S. and S.I.S.; investigation, K.S. and S.I.S.; resources, L.R.-G. and S.J.E.; data curation, K.S.; writing-original draft preparation, K.S.; writing-review and editing, S.I.S., L.R.-G., and S.J.E.; visualization, K.S.; supervision, K.S.; project administration, S.I.S.; funding acquisition, S.I.S. and S.J.E. All authors have read and agreed to the published version of the manuscript.

Funding: This research was funded by the Michigan Craft Beverage Council. Steven Safferman is also funded on the Hatach Multistate project Number MICL04141, Onsite Wastewater Treatment Systems: Assessing the Impact of Climate Variability and Climate Change, and MICL02471, Highest Value Rural Waste Management Strategies. 
Acknowledgments: The authors would like to acknowledge project participation from Joanne Davidhizar of Michigan State University Extension, Geosyntec Consultants, and MetaMateria Technologies. We would like to thank Brynn Chesney and Rachelle Crow for their significant contributions to the studies in this project, and Kiran Lantrip and Corrine Zeeff for their dedication in data collection. We would like to acknowledge Phil Hill and Steve Marquie for their expert assistance in constructing the experiments and Abby Pritchard of the Statistics Office at MSU for assistance with the statistical analysis. Lastly, we would like to show thanks to Burgdorf's Winery for providing the wastewater used in this project.

Conflicts of Interest: The authors declare no conflict of interest.

\section{References}

1. Roca, P. 2019 Statistical Report on World Vitiviniculture; International Organisation of Vine and Wine Intergovernmental Organisation: Paris, France, 2019.

2. Wines Vines Analytics. Statistics-Wines Vines Analytics. Available online: https://winesvinesanalytics.com/ statistics/winery/ (accessed on 14 October 2019).

3. Michigan Grape and Wine Industry Council. Fast Facts. Available online: https://www.michiganwines.com/ fast-facts (accessed on 3 June 2019).

4. United States Department of Agriculture (USDA). Michigan Grape Inventory 2016-2017; USDA: Washington, DC, USA; NASS: Lansing, MI, USA, 2017.

5. Michigan Grape and Wine Industry Council. Michigan Wines: About. Available online: https://www. michiganwines.com/docs/About/mi_wine_fast_factsrev.pdf (accessed on 4 June 2019).

6. Bolzonella, D.; Papa, M.; Da Ros, C.; Anga Muthukumar, L.; Rosso, D. Winery wastewater treatment: A critical overview of advanced biological processes. Crit. Rev. Biotechnol. 2019, 39, 489-507. [CrossRef] [PubMed]

7. Flores, L.; Garcia, J.; Pena, R.; Garfi, M. Constructed wetlands for winery wastewater treatment: A comparative life cycle assessment. Sci. Total Environ. 2019, 659, 1567-1576. [CrossRef] [PubMed]

8. Howell, C.L.; Myburgh, P.A.; Lategan, E.L.; Hoffman, J.E. Seasonal variation in composition of winery wastewater in the breede river valley with respect to classical water quality parameters. S. Afr. J. Enol. Vitic. 2016, 37, 31-38. [CrossRef]

9. Mosse, K.P.M.; Patti, A.F.; Christen, E.W.; Cavagnaro, T.R. Review: Winery wastewater quality and treatment options in Australia. Aust. J. Grape Wine Res. 2011, 17, 111-122. [CrossRef]

10. Petruccioli, M.; Duarte, J.C.; Federici, F. High-rate aerobic treatment of winery wastewater using bioreactors with free and immobilized activated sludge. J. Biosci. Bioeng. 2000, 90, 381-386. [CrossRef]

11. Serrano, L.; de la Varga, D.; Ruiz, I.; Soto, M. Winery wastewater treatment in a hybrid constructed wetland. Ecol. Eng. 2011, 37, 744-753. [CrossRef]

12. Shepherd, H.L.; Grismer, M.E.; Tchobanoglous, G. Treatment of high-strength winery wastewater using a subsurface-flow constructed wetland. Water Environ. Res. 2001, 73, 394-403. [CrossRef]

13. Malandra, L.; Wolfaardt, G.; Zietsman, A.; Viljoen-Bloom, M. Microbiology of a biological contactor for winery wastewater treatment. Water Res. 2003, 37, 4125-4134. [CrossRef]

14. Chapman, J.; Correll, R.; Ladd, J. Removal of soluble organic carbon from winery and distillery wastewaters by application to soil. Aust. J. Grape Wine Res. 1995, 1, 39-47. [CrossRef]

15. Andreottola, G.; Foladori, P.; Nardelli, P.; Denicolo, A. Treatment of winery wastewater in a full-scale fixed bed biofilm reactor. Water Sci. Technol. 2005, 51, 71-79. [CrossRef]

16. Arienzo, M.; Christen, E.W.; Quayle, W.C. Phytotoxicity testing of winery wastewater for constructed wetland treatment. J. Hazard. Mater. 2009, 169, 94-99. [CrossRef] [PubMed]

17. Artiga, P.; Ficara, E.; Malpei, F.; Garrido, J.M.; Méndez, R. Treatment of two industrial wastewaters in a submerged membrane bioreactor. Desalination 2005, 179, 161-169. [CrossRef]

18. Beck, C.; Prades, G.; Sadowski, A.-G. Activated sludge wastewater treatment plants optimisation to face pollution overloads during grape harvest periods. Water Sci. Technol. 2005, 51, 81-88. [CrossRef] [PubMed]

19. Braz, R.; Pirra, A.; Lucas, M.S.; Peres, J.A. Combination of long term aerated storage and chemical coagulation/flocculation to winery wastewater treatment. Desalination 2010, 263, 226-232. [CrossRef]

20. Bustamante, M.A.; Paredes, C.; Moral, R.; Moreno-Caselles, J.; Pérez-Espinosa, A.; Pérez-Murcia, M. Uses of winery and distillery effluents in agriculture: Characterisation of nutrient and hazardous components. Water Sci. Technol. 2005, 51, 145-151. [CrossRef] [PubMed] 
21. Coetzee, G.; Malandra, L.; Wolfaardt, G.; Viljoen-Bloom, M. Dynamics of a microbial biofilm in a rotating biological contactor for the treatment of winery effluent. Water SA 2004, 30, 407-412. [CrossRef]

22. Colin, T.; Bories, A.; Sire, Y.; Perrin, R. Treatment and valorisation of winery wastewater by a new biophysical process (ECCF®). Water Sci. Technol. 2005, 51, 99-106. [CrossRef]

23. Cusick, R.D.; Kiely, P.D.; Logan, B.E. A monetary comparison of energy recovered from microbial fuel cells and microbial electrolysis cells fed winery or domestic wastewaters. Int. J. Hydrog. Energy 2010, 35, 8855-8861. [CrossRef]

24. Eusébio, A.; Petruccioli, M.; Lageiro, M.; Federici, F.; Duarte, J.C. Microbial characterisation of activated sludge in jet-loop bioreactors treating winery wastewaters. J. Ind. Microbiol. Biotechnol. 2004, 31, $29-34$. [CrossRef]

25. Fumi, M.D.; Parodi, E.; Parodi, G.; Silva, A.; Marchetti, R. Optimisation of long-term activated-sludge treatment of winery wastewater. Bioresour. Technol. 1995, 52, 45-51. [CrossRef]

26. Moletta, R. Winery and distillery wastewater treatment by anaerobic digestion. Water Sci. Technol. 2005, 51, 137-144. [CrossRef] [PubMed]

27. Montalvo, S.; Guerrero, L.; Rivera, E.; Borja, R.; Chica, A.; Martín, A. Kinetic evaluation and performance of pilot-scale fed-batch aerated lagoons treating winery wastewaters. Bioresour. Technol. 2010, 101, 3452-3456. [CrossRef] [PubMed]

28. Mosteo, R.; Ormad, P.; Mozas, E.; Sarasa, J.; Ovelleiro, J.L. Factorial experimental design of winery wastewaters treatment by heterogeneous photo-Fenton process. Water Res. 2006, 40, 1561-1568. [CrossRef] [PubMed]

29. Petruccioli, M.; Cardoso Duarte, J.; Eusebio, A.; Federici, F. Aerobic treatment of winery wastewater using a jet-loop activated sludge reactor. Process Biochem. 2002, 37, 821-829. [CrossRef]

30. Rizzo, L.; Lofrano, G.; Belgiorno, V. Olive Mill and Winery Wastewaters Pre-Treatment by Coagulation with Chitosan. Sep. Sci. Technol. 2010, 45, 2447-2452. [CrossRef]

31. Ruiz, C.; Torrijos, M.; Sousbie, P.; Lebrato Martinez, J.; Moletta, R.; Delgenes, J.P. Treatment of winery wastewater by an anaerobic sequencing batch reactor. Water Sci. Technol. 2002, 45, 219-224. [CrossRef]

32. Torrijos, M.; Moletta, R. Winery wastewater depollution by sequencing batch reactor. Water Sci. Technol. 1997, 35, 249. [CrossRef]

33. Valderrama, C.; Ribera, G.; Bahí, N.; Rovira, M.; Giménez, T.; Nomen, R.; Lluch, S.; Yuste, M.; Martinez-Lladó, X. Winery wastewater treatment for water reuse purpose: Conventional activated sludge versus membrane bioreactor (MBR): A comparative case study. Desalination 2012, 306, 1-7. [CrossRef]

34. Vlyssides, A.; Barampouti, E.; Mai, S. Wastewater characteristics from Greek wineries and distilleries. Water Sci. Technol. 2005, 51, 53-60. [CrossRef]

35. Wolmarans, B.; De Villiers, G.H. Start-up of a UASB effluent treatment plant on distillery wastewater. Water $S A$ 2002, 28, 63-68. [CrossRef]

36. Zhang, Z.Y.; Jin, B.; Bai, Z.H.; Wang, X.Y. Production of fungal biomass protein using microfungi from winery wastewater treatment. Bioresour. Technol. 2008, 99, 3871-3876. [CrossRef]

37. Anastasiou, N.; Monou, M.; Mantzavinos, D.; Kassinos, D. Monitoring of the quality of winery influents/effluents and polishing of partially treated winery flows by homogeneous Fe(II) photo-oxidation. Desalination 2009, 248, 836-842. [CrossRef]

38. Kirzhner, F.; Zimmels, Y.; Shraiber, Y. Combined treatment of highly contaminated winery wastewater. Sep. Purif. Technol. 2008, 63, 38-44. [CrossRef]

39. Nujic, M.; Milinkovic, D.; Habuda-Stanic, M. Nitrate removal from water by ion exchange. Croat. J. Food Sci. Technol. 2017, 9, 182-186. [CrossRef]

40. Chaffin, J.D.; Mishra, S.; Kane, D.D.; Bade, D.L.; Stanislawczyk, K.; Slodysko, K.N.; Jones, K.W.; Parker, E.M.; Fox, E.L. Cyanobacterial blooms in the central basin of Lake Erie: Potentials for cyanotoxins and environmental drivers. J. Great Lakes Res. 2019, 45, 277-289. [CrossRef]

41. Kumar, P.; Hegde, K.; Brar, S.K.; Cledon, M.; Kermanshahi-pour, A. Potential of biological approaches for cyanotoxin removal from drinking water: A review. Ecotoxicol. Environ. Saf. 2019, 172, 488-503. [CrossRef]

42. Julien, R.; Safferman, S. Evaluation of food processing wastewater loading characteristics on metal mobilization within the soil. J. Environ. Sci. Health Part A 2015, 50, 1452-1457. [CrossRef]

43. Bartlett, H.R. State Waste Discharge General Permit for Discharges from Wineries; State of Washington Department of Ecology, Ed.; State of Washington Department of Ecology: Olympia, WA, USA, 2018. 
44. New York State Department of Environmental Conservation. Comment End-Proposed Permit for Wastewater Discharges. In Advanced Notice of Proposed Permit for Discharges of Winery, Brewery and Hard Cidery Wastewater to Groundwater; New York State Department of Environmental Conservation: Albany, NY, USA, 2018.

45. Campbell, E.L.; Safferman, S.I. Design criteria for the treatment of milking facility wastewater in a cold weather vertical flow wetland. Trans. ASABE 2015, 58, 1509-1519.

46. Rozema, E.R.; Rozema, L.R.; Zheng, Y. A vertical flow constructed wetland for the treatment of winery process water and domestic sewage in Ontario, Canada: Six years of performance data. Ecol. Eng. 2016, 86, 262-268. [CrossRef]

47. Campbell, E.L. Design Criteria for the Treatment of Milking Facility Wastewater in a Cold Weather Vertical Flow Wetland. Master's Thesis, Michigan State University, East Lansing, MI, USA, 2014.

48. Davis, M.L. Water and Wastewater Engineering: Design Principles and Practice; McGraw-Hill Education: New York, NY, USA, 2011.

49. Chang, J.-J.; Wu, S.-Q.; Dai, Y.-R.; Liang, W.; Wu, Z.-B. Treatment performance of integrated vertical-flow constructed wetland plots for domestic wastewater. Ecol. Eng. 2012, 44, 152-159. [CrossRef]

50. Rodriguez-Gonzalez, L.; Miriyala, A.; Rice, M.; Delgado, D.; Marshall, J.; Henderson, M.; Ghebremichael, K.; Mihelcic, J.R.; Ergas, S.J. A Pilot-scale hybrid adsorption biological treatment system (habits) for nitrogen removal in onsite wastewater treatment. ASCE J. Sustain. Water Built Environ. 2020, 6, 04019014. [CrossRef]

51. Krayzelova, L.; Lynn, T.J.; Banihani, Q.; Bartacek, J.; Jenicek, P.; Ergas, S.J. A Tire-Sulfur Hybrid Adsorption Denitrification (T-SHAD) process for decentralized wastewater treatment. Water Res. 2014, 61, $191-199$. [CrossRef] [PubMed]

52. Lahav, O.; Green, M. Ammonium removal using ion exchange and biological regeneration. Water Res. 1997, 32, 2019-2028. [CrossRef]

53. Rodriguez-Gonzalez, L.; Payne, K.; Trotz, M.; Ergas, S.J. Hybrid Adsorption and Biological Treatment Systems (HABiTs) for onsite wastewater treatment. Proc. Water Environ. Fed. 2015, 2015, 4660-4672. [CrossRef]

54. Hamester, M.R.R.; Balzer, P.S.; Becker, D. Characterization of calcium carbonate obtained from oyster and mussel shells and incorporation in polypropylene. Mater. Res. 2012, 15, 204-208. [CrossRef]

55. Shulluck, T. A report on the use of shredded scrap tires in onsite sewage disposal systems. In Envirologic; State of Vermont Deptartment of Environmental Conservation: Montpelier, VT, USA, 1990.

56. Safferman, S.; Dong, Y.; Thelen, J.; Costantini, L.; Saber, L.; Schorr, J.R.; Sengupta, S.; Revur, R. Phosphorus Removal from Domestic Wastewater Using Engineered Nano-Media. In Proceedings of the 2015 National Onsite Wastewater Recycling Association, Virginia Beach, VA, USA, 4-6 November 2015.

57. Kadlec, R.H.; Wallace, S. Treatment Wetlands; CRC Press: Boca Raton, FL, USA, 2008.

58. Lakeshore Environmental, Inc. A Study on the Effectiveness of Onsite Wastewater Treatment Systems for Michigan Wineries; Michigan Department of Agriculture \& Rural Development: Grand Rapids, MI, USA, 2015.

59. De Klerk, A. Voidage variation in packed beds at small column to particle diameter ratio. AIChE J. 2003, 49, 2022-2029. [CrossRef]

60. Dong, Y.; Safferman, S.; Miller, S.; Hruby, J.; Bratt, D. Effectiveness of food processing wastewater irrigation. In Proceedings of the 90th Annual Water Environment Federation Exhibition Conference, Phoenix Convention Center, Phoenix, AZ, USA, 3-5 May 2017; pp. 3859-3866.

61. Arienzo, M.; Christen, E.W.; Quayle, W.; Di Stefano, N. Development of a low-cost wastewater treatment system for small-scale wineries. Water Environ. Res. 2009, 81, 233-241. [CrossRef]

62. Wang, M.; Zhang, D.Q.; Dong, J.W.; Tan, S.K. Constructed wetlands for wastewater treatment in cold climate-A review. J. Environ. Sci. 2017, 57, 293-311. [CrossRef]

63. Rodriguez-Gonzalez, L.C. Advanced Treatment Technologies for Mitigation of Nitrogen and Off-flavor Compounds in Onsite Wastewater Treatment and Recirculating Aquaculture Systems. Ph.D. Thesis, University of South Florida, Tampa, FL, USA, 2017.

64. Schorr, J.R.; Sengupta, S.; Revur, R.; Helferich, R.; Safferman, S. Phosphorous Removal and Recovery Using Nanotechnology. In Aquananotechnology; CRC Press: Boca Raton, FL, USA, 2014; pp. 654-673.

65. Hach. EPA Compliant Methods. Available online: https://www.hach.com/epa (accessed on 8 January 2020).

66. Andreottola, G.; Foladori, P.; Ziglio, G. Biological treatment of winery wastewater: An overview. Water Sci. Technol. 2009, 60, 1117-1125. [CrossRef] 
67. Artiga, P.; Carballa, M.; Garrido, J.; Mendez, R. Treatment of winery wastewaters in a membrane submerged bioreactor. Water Sci. Technol. 2007, 56, 63-69. [CrossRef]

68. López-Palau, S.; Dosta, J.; Mata-Alvarez, J. Start-up of an aerobic granular sequencing batch reactor for the treatment of winery wastewater. Water Sci. Technol. 2009, 60, 1049-1054. [CrossRef]

69. Tchobanoglous, G.; Stensel, H.D.; Tsuchihashi, R.; Burton, F.L.; Abu-Orf, M.; Bowden, G.; Pfrang, W. Wastewater Engineering: Treatment and Resource Recovery, 5th ed.; McGraw-Hill Education: New York, NY, USA, 2014; pp. 93-95.

70. American Water Works Association; Economic and Engineering Services Inc. Nitrification; United States Environmental Protection Agency: Washington, DC, USA, 2002.

71. Aponte-Morales, V.E.; Payne, K.A.; Cunningham, J.A.; Ergas, S.J. Bioregeneration of chabazite during nitrification of centrate from anaerobically digested livestock waste: Experimental and modeling studies. Environ. Sci. Technol. 2018, 52, 4090-4098. [CrossRef]

72. Amini, A.; Aponte-Morales, V.; Wang, M.; Dilbeck, M.; Lahav, O.; Zhang, Q.; Cunningham, J.A.; Ergas, S.J. Cost-effective treatment of swine wastes through recovery of energy and nutrients. Waste Manag. 2017, 69, 508-517. [CrossRef]

73. Kadlec, R.; Knight, R. Treatment Wetlands; Lewis Publisher: Boca Raton, FL, USA, 1996.

74. Wen-Ling, Z.; Li-Hua, C.; Ouyang, Y.; Cui-Fen, L.; Xiao-Dan, T. Kinetic adsorption of ammonium nitrogen by substrate materials for constructed wetlands. Pedosphere 2011, 21, 454-463.

75. Bae, W.; Baek, S.; Chung, J.; Lee, Y. Optimal operational factors for nitrite accumulation in batch reactors. Biodegradation 2001, 12, 359-366. [CrossRef]

76. Masi, F.; Rochereau, J.; Troesch, S.; Ruiz, I.; Soto, M. Wineries wastewater treatment by constructed wetlands: A review. Water Sci. Technol. 2015, 71, 1113-1127. [CrossRef]

77. Tursi, A.; Chatzisymeon, E.; Chidichimo, F.; Beneduci, A.; Chidichimo, G. Removal of endocrine disrupting chemicals from water: Adsorption of bisphenol-A by biobased hydrophobic functionalized cellulose. Int. J. Environ. Res. Public Health 2018, 15, 2419. [CrossRef]

78. Brito, A.G.; Peixoto, J.; Oliveira, J.M.; Oliveira, J.A.; Costa, C.; Nogueira, R.; Rodrigues, A. Brewery and winery wastewater treatment: Some focal points of design and operation. In Utilization of by-Products and Treatment of Waste in the Food Industry; Springer: Berlin/Heiderbeg, Germany, 2007; pp. 109-131.

79. Masi, F.; Conte, G.; Martinuzzi, N.; Pucci, B. Winery high organic content wastewaters treated by constructed wetlands in Mediterranean climate. In Proceedings of the 8th International Conference on Wetland Systems for Water Pollution Control, Arusha, United Republic of Tanzania, 16-19 September 2002; pp. 274-282.

80. Michigan Department of Environmental Quality. Guidance for the Design of Land Treatment Systems Utilized at Wineries; Water Resources Division, Groundwater Program, Ed.; State of Michigan: Lansing, MI, USA, 2015.

81. Boxman, S.E.; Kruglick, A.; McCarthy, B.; Brennan, N.P.; Nystrom, M.; Ergas, S.J.; Hanson, T.; Main, K.L.; Trotz, M.A. Performance evaluation of a commercial land-based integrated multi-trophic aquaculture system using constructed wetlands and geotextile bags for solids treatment. Aquac. Eng. 2015, 69, 23-36. [CrossRef]

82. Ioannou, L.A.; Li Puma, G.; Fatta-Kassinos, D. Treatment of winery wastewater by physicochemical, biological and advanced processes: A review. J. Hazard. Mater. 2015, 286, 343-368. [CrossRef]

83. Suvankar, S.; Schorr, J.R.; Revur, R.; Marth, T.; Safferman, S.I. Phosphorus removal using engineered nano-media. In Proceedings of the WEFTEC 2016, New Orleans, LA, USA, 24-28 September 2016.

84. Westholm, L.J. Substrates for phosphorus removal-Potential benefits for on-site wastewater treatment? Water Res. 2006, 40, 23-36. [CrossRef]

(C) 2020 by the authors. Licensee MDPI, Basel, Switzerland. This article is an open access article distributed under the terms and conditions of the Creative Commons Attribution (CC BY) license (http://creativecommons.org/licenses/by/4.0/). 